Wright State University

CORE Scholar

$5-1994$

\title{
For Information Specialists: Interpretations of Reference and Bibliographic Work
}

\author{
Stephen Paul Foster Ph.D. \\ Wright State University - Main Campus, stephen.foster@wright.edu
}

Follow this and additional works at: https://corescholar.libraries.wright.edu/ul_pub

Part of the Library and Information Science Commons

\section{Repository Citation \\ Foster, S. P. (1994). For Information Specialists: Interpretations of Reference and Bibliographic Work. College and Research Libraries, 55 (3), 274-275. \\ https://corescholar.libraries.wright.edu/ul_pub/140 \\ This Book Review is brought to you for free and open access by the University Libraries at CORE Scholar. It has been accepted for inclusion in University Libraries' Staff Publications by an authorized administrator of CORE Scholar. For more information, please contact library-corescholar@wright.edu.}


might take the lead in mapping these new frontiers.

If this volume represents a forceful social critique of the current state of information technologies in academia, it is no Luddite call for return to an idealized pretechnological past. In fact, it is their clear recognition of the powerful potential of new information technologies that motivates colloquium participants to demand that these be fully realized for women and other marginalized social groups. In the contested terrain of information technology, it is only by addressing the embedded social relations that this technolandscape of enticing promises will prove more than an exclusive preserve.-Joan Ariel, University of California, Irvine.

White, Howard D., Marcia J. Bates, and Patrick Wilson. For Information Specialists: Interpretations of Reference and Bibliographic Work. Norwood, N.J.: Ablex, 1992. 310 p. $\$ 24.50$ (ISBN 089391-983-7).

This collection of articles by three library school faculty focuses on three aspects of information work. Each is the topic of one of the book's three main sections: reference work, bibliographic writing, and literature searching. In the short fourth and final section, Howard White sets out to provide an integrated view of what information specialists do.

In his introduction White says that the authors "offer ... insights into human aspects of the profession [i.e., information work] that are seldom treated elsewhere." With a few exceptions his promise, however, goes largely unfulfilled. While some interesting notions emerge, it is difficult on the whole to say to whom his book would appeal. It lacks a solid focus, and the reader moves through a somewhat bewildering array of topics with quite different approaches.

Five of the book's eleven chapters are rewrites of articles that appeared over the years in journals. There is a short article on the nature of a reference book, replete with charts and empirical data, a speculative treatise on the uniqueness of librarians and information specialists, and several articles about techniques for conducting online searches. At one point in the book we have a discussion of Karl Popper's "world 3" theory as it relates to information science, while at another we get a discussion of online versus manual database searching infused with neologisms such as BIBBLE: "To BIBBLE is to look for a bibliography already prepared, before launching into the effort of preparing one."

What theme or themes unite these disparate pieces is far from clear despite White's claim that "there is a great deal of theme-passing from author to author." The articles on literature searching seem to have a specialized pedagogical purpose that little serves the general interpretive ambitions of the book. Many of the book's observations seem to be commonsense notions recast in an academic parlance sufficiently ponderous so as to make them sound insightful. "Libraries, as guarantors of 'permanent publication,' ratify the choices of publishers generally, but of some much more than others."

In the final chapter, however, White makes some observations that raise important questions about librarianship. He writes that most librarians, once finished with school, do not read library and information science research literature because "they do not need to; or, as they would claim, because it does not tell them what they need to know." A remarkable admission! If it so, why, we might ask, should librarians read this book? What does White's observation suggest about the relevance of professional research to professional practice? If a librarian, upon completing formal training in the library and information science, has little need for the research of library and information science, then what is its purpose? What is it about the whole professional educational endeavor that makes library and information science relevant to formal education but irrelevant afterward? Nevertheless, White's observation is, in my view, the most important of the book and raises far-reaching questions.

White then immediately adds something that makes the above an even more interesting and pressing issue. "The 
mandate of librarians to keep certain segments of external memory alive is essentially a political task, calling for knowledge that is ethical and situationspecific rather than technical and general in the style of L\&IS research." This claim, if true, complicates both our view of the profession and our notion of the kind of education that is most appropriate for librarians. Librarians, according to this view, would be ethicists, involved in making important value judgments in the administration of institutional resources. Critical to their success would be a deep understanding of the functions and limitations of the particular institutions they serve, hence the importance of the"situation-specific" nature of their knowledge. Some of the important issues in current librarianship seem to illustrate this view. Right to know, access versus ownership, and resistance to censorship are major concerns involving questions of social ethics insofar as library services are valued as moderately scarce resources to which people can make moral, political and legal claims.

It is disappointing that White does not develop his idea of librarian as ethicist. He does say that "aside from their bibliographic expertise, the 'science' of working librarians is policy ..." Here then reemerges a tension and ambiguity between the librarian as technician; i.e., information specialist, and librarian as humanist; i.e., as ethicist and public policy advocate. An exploration of this tension might have some bearing on the phenomenon of library school closings in recent years-since the closings are due, many librarians argue, to fundamental misconceptions about the nature and value of the profession. For Information Specialists may be of use and interest for library school students, but for librarians its points of interest are few.Stephen P. Foster, Central Michigan University, Mt. Pleasant, Michigan.

Rosenberg, Jane Aikin. The Nation's Great Library: Herbert Putnam and the Library of Congress, 1899-1939. Champaign, Ill.: Univ. of Illinois Pr., 1993. 235p. \$39.95 (ISBN 0-252-02110-4).
Jane Rosenberg has written a fine book on Herbert Putnam's forty-year tenure at the Library of Congress (LC). It is a solid and readable history of several complex issues: LC's role in American library development; the vicissitudes of Congressional support; the library community's reactions to Putnam's management of LC services to libraries; and the role of LC in the development of librarianship as a profession. In relatively few text pages (165), relatively many pages of notes (51), nineteen period pictures, and a graceful "Essay on Sources," the author bestows equal measures of scholarship, but somewhat uneven insight on each of her four stated themes.

The book is a rewritten version of the author's 1988 dissertation, "The Library of Congress and the Professionalization of American Librarianship, 1896-1939." Rosenberg's discussion of this theme is definitive. Similarly, her treatment of the intertwined topics of LC's role in American library development and Putnam's vision of LC as the national library may be confidently labeled "required reading"

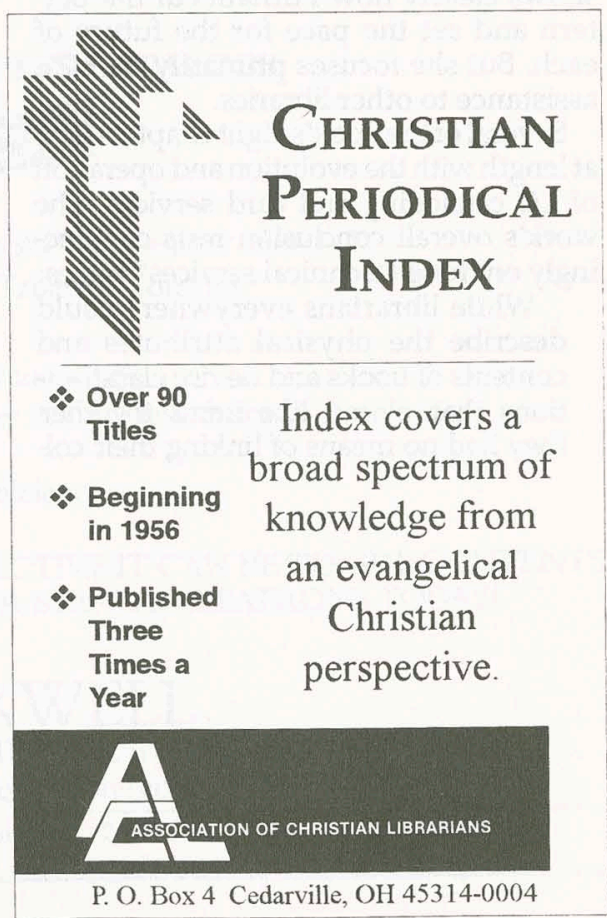

